\title{
AZ ÚJ MAGYARORSZÁG VIDÉKFEJLESZTÉSI PROGRAM TERÜLETI HATÁSAI
}

REGIONAL IMPACTS OF THE NEW HUNGARY RURAL DEVELOPMENT PROGRAM

\section{Keszthelyi Krisztián}

mestertanár

Szent István Egyetem, Gazdaság és Társadalomtudományi Kar

E-mail: keszthelyi.krisztian@gtk.szie.hu

\section{Összefoglalás}

Munkám elkészítését alapvetően az motiválta, hogy megvizsgáljam a magyar mezőgazdasági pályázatok rendszerének müködését, mivel ezen kérdéskör alapos elemzése után számos módosító javaslattal szándékozom hozzájárulni a rendszer további fejlesztéséhez, épüléséhez, megítélésem szerint hatékonyabb müködésének elősegítése érdekében. Elemzéseim fontos részét képezték a kérdéskör területi hatásainak értelmezése is, melynek eredményeiből mutatok be párat. Összességében az a kép rajzolódott ki, hogy a hazai mezőgazdasági támogatási rendszer hatékonyabb müködtetésére igen nagy szükség lenne, valamint igen nagy tartalékok mutatkoznak a hatékonyság növelés szempontjából.

\begin{abstract}
The preparation of my thesis was basically motivated to examine the operation of the Hungarian subsidy system in order to give some modifying proposals to develop the efficiency of the system. The territorial effects have played main role in my studies, which's results are presented in this study. On the whole the result is identified that the subsidy system needs more effective operation and there are potentials to increase the efficiency.
\end{abstract}

Kulcsszavak: vidékfejlesztés, helyi gazdaságfejlesztés, agrár támogatások JEL besorolás: $H 1, H 75, R 58$

LCC: S1-972, S770-790.3

\section{Bevezetés}

A hazai agrártámogatások érvényesülését nagyban meghatározza az a természeti, társadalmi és gazdasági környezet állapot, melyek közül munkámban a társadalmi és gazdasági elemekre fókuszálok. Mint ahogy azt többek között HAJDÚ Z., TÓTH T. is megállapítja, hogy Magyarország településállománya a XIX. század óta meglehetős állandóságot mutat. Ahogyan azt a 1. sz. ábrán is megnézhetjük, a Pest megye és Budapest által megtestesített Középmagyarországi régió minden tekintetben kimagaslik az országos eredmények közül. Hazánkban a legnagyobb területegységre jutó településszám és a legmagasabb népsürüség is ezen régióhoz kapcsolódik. (Bakos -Tóth, 2016) Akár nagyságrendileg négyszeres adatok is kimutathatók a legalacsonyabb megyéhez képes. Ezen különbségek nagyban meghatározzák, befolyásolják a területi szerkezetet és ezen keresztül a területfejlesztést, és a támogatások felhasználását is. 


\section{A megyék, régiók és országrészek népsürüsége hazánkban 2017-ben (fő/ $/ \mathrm{km}^{2}$ )}

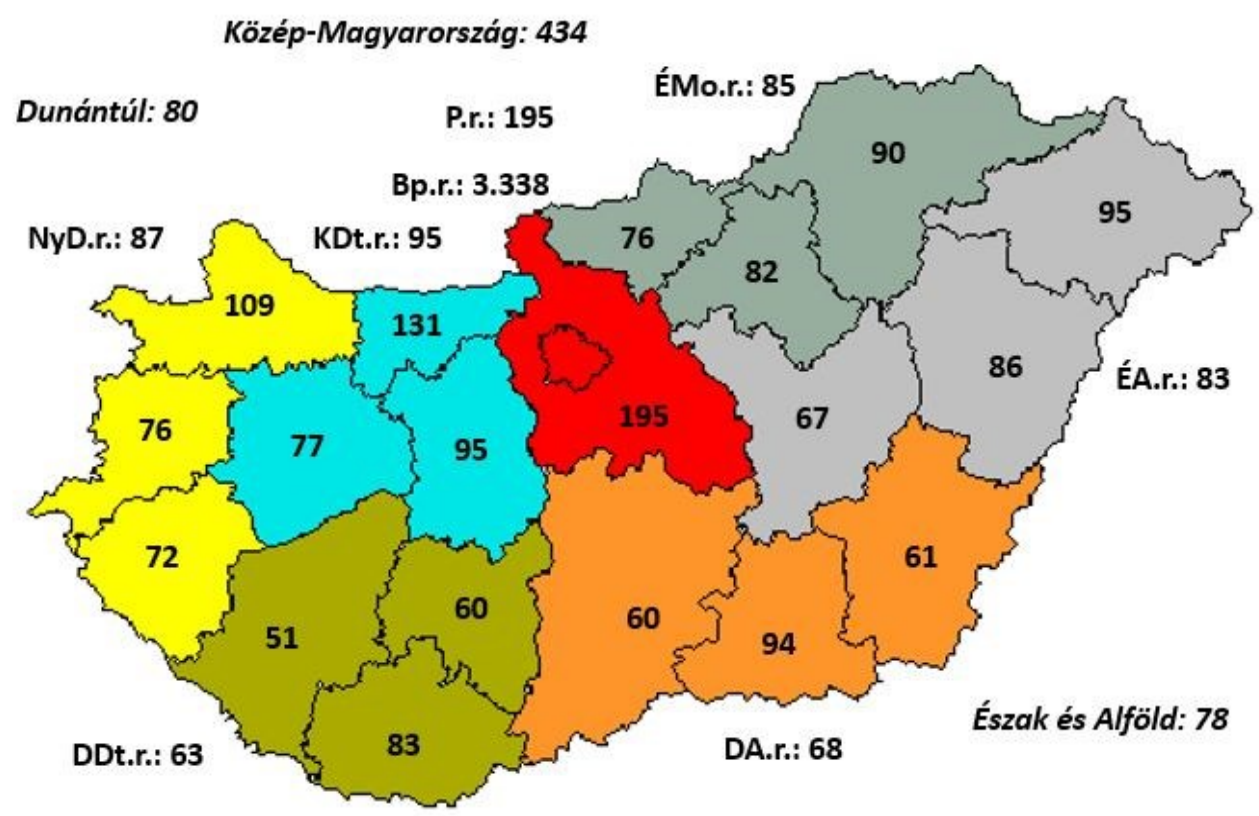

Magyarország átlag: 105

\section{1. ábra: Területi egységek népsürüsége}

Forrás: KSH adatok alapján, Urbánné Malomsoki M.- Tóth T. 2018. in (TÓTH 2019)

"A népsürüség regionális különbségeit mindenekelőtt a gazdasági hasznosítás intenzitása alakítja. A megyei szinten mért népsürüségben ugyan közel háromszoros különbségek is adódnak, de még a ritkábban lakott megyék népsürüsége is -európai viszonylatban- közepesnek mondható. Sokkal nagyobb különbségek mutatkoznak a településsürüségben. Ebből a szempontból markánsan eltérő térségekre különül el az ország. Míg az Alföldön 1,3-1,4 település jut 100 km2-re, addig ez az érték a Dunántúl egyes megyéiben 6 felett van.” (TÓTH 2019)

Munkámban nem a teljes ÚMVP hatásait vizsgáltam, hanem a program által kiemelt állattenyésztési alágazat helyzetének a vizsgálatát tartottam különösen fontosnak, vagyis, hogy az ÚMVP legjelentősebb forráslekötéssel érintett állattartó telepi támogatások miképpen hasznosultak, hogyan hatottak a támogatások a gazdaságok egyes pénzügyi és naturális mutatóira, illetve vannak-e területi különbségek a támogatások odaítélése, és felhasználása között.

Az általam vizsgált időtáv a 2010-2015 közötti időszakot öleli fel, ennek oka, hogy a támogatások felhasználása időben mindig valamelyest eltolódik. A 2007-ben induló támogatási intézkedések eszközállományra, állatállományra, üzemméretre, adózás előtti eredményre gyakorolt hatásai csak 2010-ben jelentkeztek először a két majd három éves megvalósítási határidő miatt, ugyanezen okból a vizsgálati időszak végét 2015-ben határoztam meg az n+2 éves szabály alkalmazása szerint. 2015-ös év volt az első olyan gazdasági év, melyben a beruházások eredményeit már látni lehet. Ebben az évben a következő programozási időszak, azaz a Vidékfejlesztési Program még nem indult el, így annak hatásaival sem kell számolni. (Káposzta, 2001)

Munkámban fontosnak tartom a területi különbségek markáns megjelenítését, bár világviszonylatban hazánk messze nem tartozik a nagy kiterjedésű országok közé és távolról 
nézve általában a felületes szemlélődő viszonylag homogén területek együtteseként írhatja le, de ha a dolgok mélyére ásunk, akkor korántsem homogén a kép.

\section{Anyag és módszer}

Számos kutató már megállapította, hogy a társadalomtudományi, vidékfejlesztési szakterületekhez kapcsolódó, szociológiai kutatásokhoz, vidékfejlesztési adatfeltárási, elemzési feladatokhoz, az adatfeldolgozáshoz a Microsoft Office Excel, illetve az SPSS vagy PASW statisztikai programcsomag minden igényt kielégítően alkalmazhatók. A program kiválóan alkalmas a nagy adatállományokból történő adat leválogatásra, aggregálásra, több fájl egybefésülésére, szürésre, vagyis az elemzést szolgáló adatkészlet előállítására. Az így elkészült adatfájlban képezhetők mutatók, indikátorok, indexek, s az új változókkal kiegészült adatfájl további többváltozós analízisek alapjául szolgálhatnak, vagy exportálhatók más, pl. térinformatikai programok számára is olvasható formátumba." (TÓTH- KÁPOSZTA 2014)

Az ÚMVP Ex post analízishez használt adatbázisa alapján összegyüjtött adatokhoz magam is a fenti módszertant alkalmaztam.

A kutatásom során az Agrárgazdasági Kutató Intézet által hozzáférhető, támogatási és kifizetési adatokat tartalmazó, az MVH által üzemeltetett Integrált Igazgatási és Ellenőrzési Rendszerből (továbbiakban IIER) kinyert adatokat kapcsoltam össze a NAV által a társas vállalkozások beszámoló adataival, annak érdekében, hogy ne csak támogatási és kifizetési adatokat, hanem a pályázók egyes gazdálkodási adatai közötti összefüggést is vizsgáljam.

Az IIER olyan támogató informatikai ügyviteli rendszer, melynek feladata az EU Közös Agrárpolitikájában (KAP) meghatározott forrásokból és a magyar költségvetés által biztosított forrásból finanszírozott ágazati támogatások iránti kérelmek befogadása, elbírálása és a juttatások folyósítása a kedvezményezettek részére. A rendszer az összes KAP-pal kapcsolatos támogatási kérelmet kezeli, a területalapú támogatásoktól a beruházási jogcímekig. A rendszer a folyamatos fejlesztésnek köszönhetően papír nélküli ügyintézését biztosít.

Az IIER-ből kinyert adatokat regisztrációs számonként név nélkül és pontos megvalósítási hely nélkül (csak települési adatok) kaptam meg, azaz a vizsgálat során az anonimitás biztosított volt.

\section{Eredmények}

Az ÚMVP-n belül az állattartó telepek korszerüsítéséhez kapcsolódó jogcímeket a regionális ügykezelés jellemezte, azaz az agrár-környezetgazdálkodási intézkedésekhez képest, a bírálat nem megyei, hanem regionális szinten hét központban valósult meg. A döntések a regionális bírálatot követően központilag születtek meg, azaz a források nem kerültek sem regionálisan, sem megyei szinten allokálásra, országos pontozási rangsor készült az öt alintézkedésről, az állattartó telepekhez kapcsolódó öt különböző meghirdetési időszakban.

A bírálatok során régiós szempontok nem játszottak szerepet, csak területfejlesztési kérdések (hátrányos helyzetü kistérségek) kerültek értékelésre, azaz regionális szempontból a program semlegesnek volt nevezhető (és itt most nem számolok azzal, hogy egyes régiókban biztosan több hátrányos helyzetü kistérség volt).

Az igényelt és a ki is fizetett támogatások alapján az egyes megyék három jól elkülönülö csoportra oszthatók. A ÚMVP keretin belül állattartó telepek korszerüsítésére összesen 601,6 Mrd forint támogatást igényeltek az ügyfelek, amiből a program végére 224,8 Mrd forint 
támogatás került kifizetésre, ez 37\%-s országos sikerességet jelent, azonban az egyes megyéket tekintve, a területi semlegesség ellenére már jóval heterogénebb a kép.

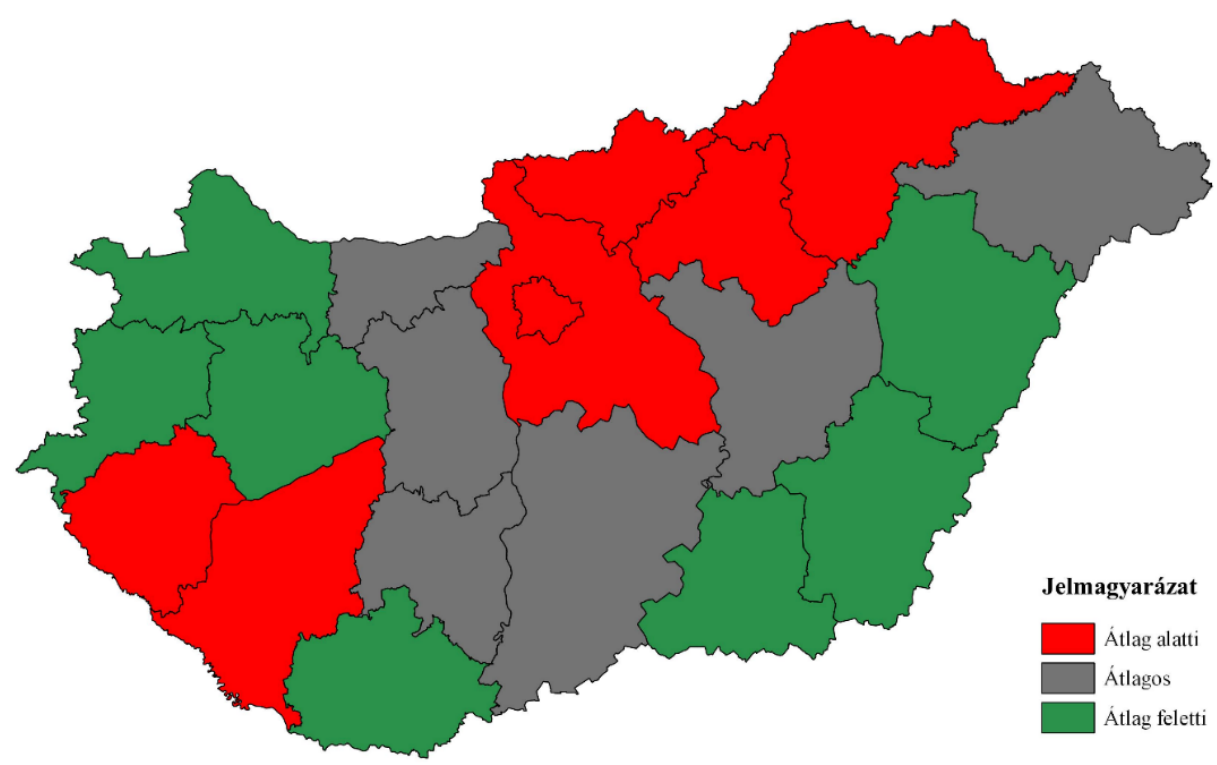

\section{2. ábra: A vizsgált öt év alatt igényelt és ki is fizetett fejlesztési támogatások sikeresség szerinti megyei eloszlása}

Forrás: IIER adatok alapján, saját szerkesztés 2019.

A sikerességet tekintve a következő besorolást alkalmazom a megyékre: a sikeresség $34 \%$ alatti az átlag alatti, $34-42 \%$ közötti az átlagos, és $42 \%$ feletti pedig átlag feletti besorolást kapott. Az előző térképpel tudom ábrázolni az egyes megyék sikerességét. (2. ábra)

Ezen jól látszik, hogy a kifizetett fejlesztési források tekintetében nem homogén a kép hét megyénk részesült átlag feletti (a megyei átlag 37 \% volt) kifizetésből melyek közül messze is kiemelkedett Veszprém megye a maga 59\%-os eredményével. Az átlag alatti kategóriába tartozó megyék közül negatív irányba lóg ki a sorból, Heves és Nógrád megye a maguk 17 és 19\%-os eredményeikkel.

Felvetődik a térképet tekintve, hogy Mezőgazdasági és Vidékfejlesztési Hivatal egyes regionális jogkörrel rendelkező kirendeltségei esetleg saját megyéjüknek kedvezően döntötteke. Veszprém, Csongrád megyék regionális jogkörrel rendelkeztek, és ezek a megyék a támogatási döntéseket illetően jelentős forrásokat nyertek és hívtak is le. Azonban ez már nem mondható el Szabolcs-Szatmár-Bereg megyéről, mely átlagosan teljesített, és a feltételezést nem támasztja alá Borsod-Abaúj-Zemplén, Pest és Zala megye sem, ahol a helyi bírálat ellenére a megyék gyengén teljesítettek.

Ezeken kívül még számos különbséget lehet felfedezni, de először is úgy vélem fontos megnézni a kiindulási állapotot még ebben a viszonylag rövidnek tekinthető időtávban is.

A fejlesztési támogatások a beruházásokat segítik elő az ágazatban, melyek eredménye a tárgyi eszköz állományban realizálódik, azaz gépekben, technológiákban és épületekben, 
ingatlanokban. Az egy üzemre jutó tárgyi eszköz állomány adatokat és azok változását mutatom be a következő ábrán.

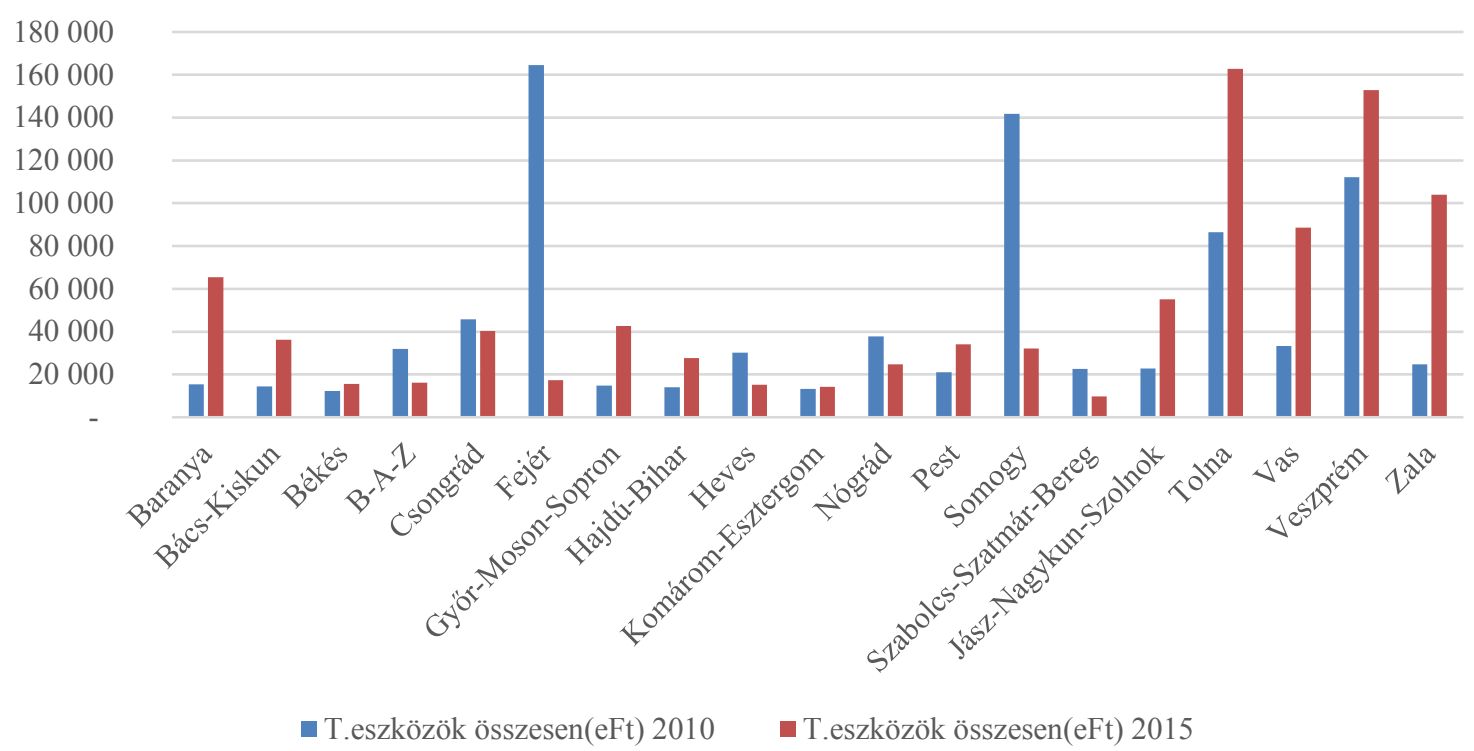

3. ábra: Mezőgazdasági tárgyi eszközök, 2010, 2015 (eFt)

Forrás: AKI adatok alapján, saját szerkesztés 2019.

Az ország megyéi a tárgyi eszközök tekintetében igen heterogén képet mutatnak Fejér, Somogy, Tolna és Veszprém megyékben az egy gazdaságra jutó tárgyi eszközállomány kiemelkedő volt 2010-ben. Míg az országos eszközállomány átlaga 2010-ben 23,3 M Ft volt, addig ezekben a megyékben az átlag meghaladta a $80 \mathrm{M}$ forintot. (3. ábra)

2015-re a támogatásoknak is köszönhetően az üzeme jutó tárgyi eszközállomány országosan 32,6 M Ft-ra nőtt, vagyis az amortizációt meghaladó beruházások - tehát nettó beruházás történt az ágazatba, ami mindenképpen pozitív. A vizsgált üzemek tárgyi eszközállománya ebben a hat éves időszakban 175 Mrd forintra nőtt, mely összeg némileg meghaladja ugyanezen időszak alatt erre a jogcímekre kifizetett támogatás összegét a 158 Mrd forintot. Bár a támogatás kb. 300 Mrd forint növekedést indukált elméletben, de figyelembe kell vennünk az értékcsökkenést és rendkívüli leírások összegét is.

Az egyes megyék adatait tekintve azonban már igen vegyes az előzőekben említett kép. A nyugati megyékben Fejér megyétől eltekintve jelentősen nőtt az egy üzemre jutó tárgyi eszköz állomány. A Fejér megyei adatok tekintetében a jelentős visszaesés inkább mintavételi hibára, a minta változására vezethető vissza, ezért ennél mélyebb következtetést levonni nem lehet.

Figyelemre méltó, hogy a jelentős állattartási potenciállal rendelkező megyékben, mint Borsodban és Szabolcs-Szatmár-Bereg megyékben az egy üzemre jutó eszközállomány nem nőtt, hanem még csökkent is a vizsgálat időszakban.

Az üzemre jutó tárgyi eszközöket tekintve az eszközkészlet belső szerkezetében is megmutatkozott a változás a két vizsgált időszak között (4. ábra). Az épületek állománya kb. 25\%-kal nőtt, ezzel szemben a müszaki berendezések (gépek, technológiai elemek), valamint tenyészállat-állomány értéke közel duplázódott. 


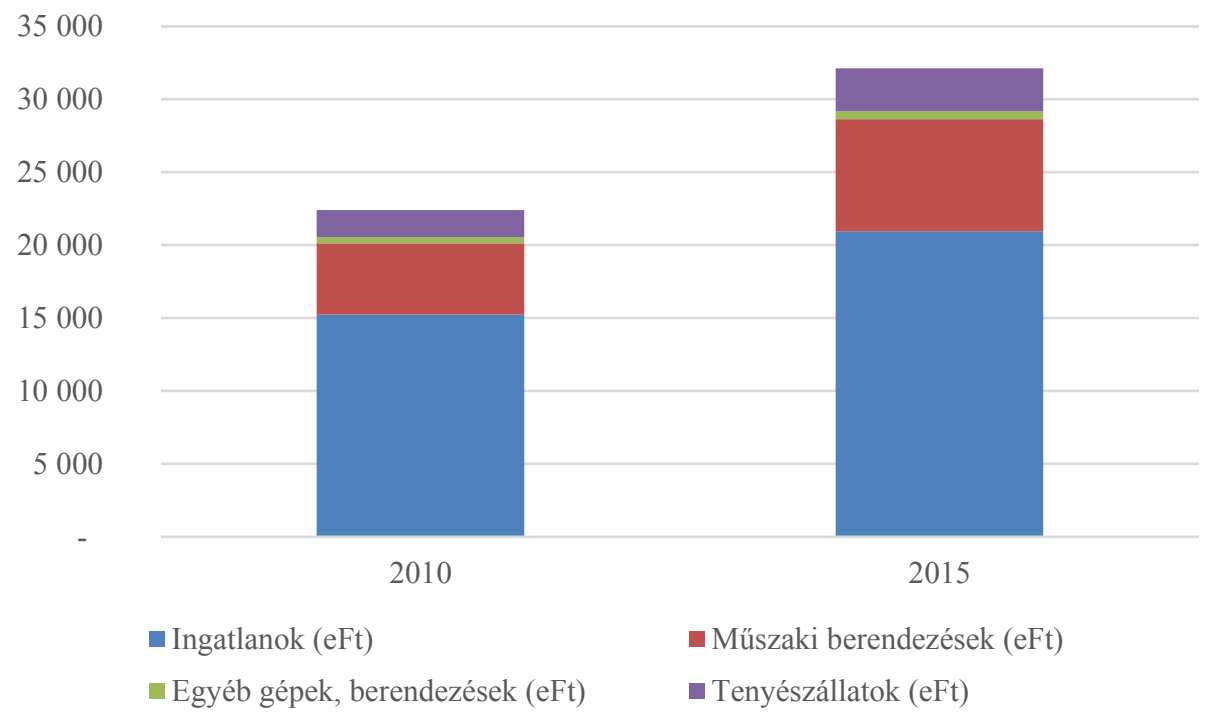

\section{4. ábra: Tárgyi eszközök részletezve, 2010, 2015 (eFt)}

Forrás: AKI adatok alapján, saját szerkesztés 2019.

A vizsgált támogatási jogcímek kimondott és markáns célja az volt, hogy az állattartás mezőgazdasági GDP-ből való részesedése növekedjen, a Magyarországon megtermelt gabonát, „bőrbe kössék”, azaz magasabb hozzáadott értéket állítsunk elö. Ez a növekedési cél elérhető extenzív és intenzív módon is, előbbi esetében az állomány egyértelmü növekedése a cél, pl. brojlercsirke és húsmarha tenyésztés esetében, míg intenzív növekedés a cél a tejelö szarvasmarha tartás esetében, ahol nem elsődleges szempont az állomány számának növelése, csak a fajlagos hozamok javítása. A sertés esetében mindkét cél megjelenik, egyrészt az állomány növelése is, de hatékonyság növelés is, mint pl. a kocaforgó érték növelése.

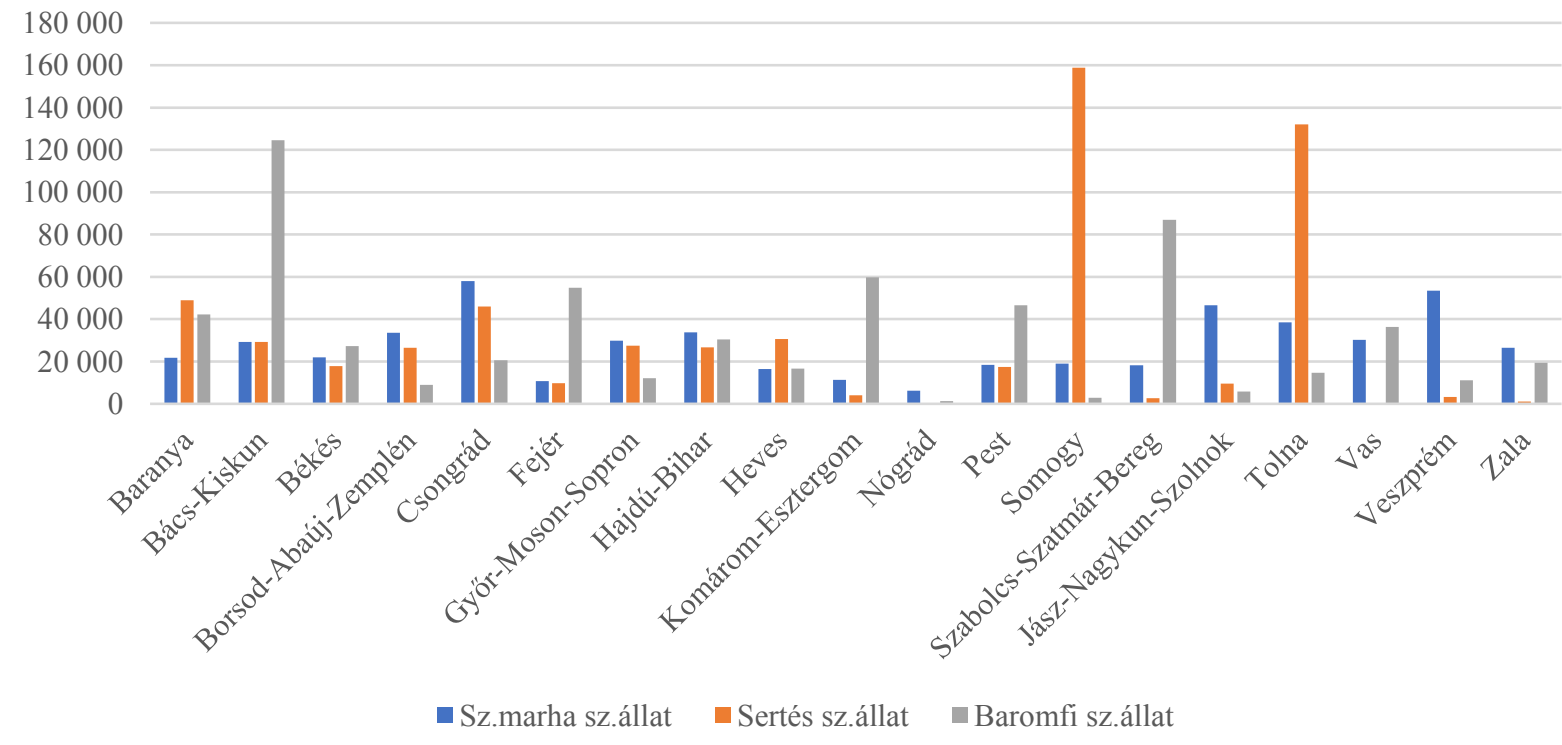

5. ábra: Megyei állatállomány, 2010 (db)

Forrás: NAV és IIER adatok alapján, saját szerkesztés 2019.

Az állatállomány tekintetében is megjelennek az eddig tapasztalt területi differenciák, jól láthatók az ábrán a markáns sertés-, szarvasmarha- és baromfitenyésztő megyéink. 
Tulajdonképpen az állatállomány és egyéb előző mutatók tekintetében a célom a 2010-es állapotok elemzése és rögzítése volt, mivel a pályázati rendszer jótékony hatásainak kimutatását egy állapotfelmérés és az ahhoz képeset megtörtént változások tudják a legpontosabban szemléltetni (5. ábra)

Az állatállományt érintően is számos változás következett be, ezen elmozdulások markánsan pozitív elöjelel valósultak meg. Átlagosan a szarvasmarha számos állatállomány 107 a sertés 128 míg a baromfi számos állat 78\%-os bővülést mutat. Az átlagos bővülés mellett voltak igen kiugró eredmények is pl. a baromfi esetében Jász-Nagykun-Szolnok 630 és Tolna 181\%-os növekedése látványos, a szarvasmarha vonatkozásában Hajdu-Bihar 216 Jász-NagykunSzolnok 151 és még három megye hozott 130\% körüli értéket. A sertésnél Zala 402, BácsKiskun 257, Tolna és Borsod-Abaúj-Zemplén 215, Veszprém 214 \%-os fejlődése igazán kimagasló. (6. ábra)

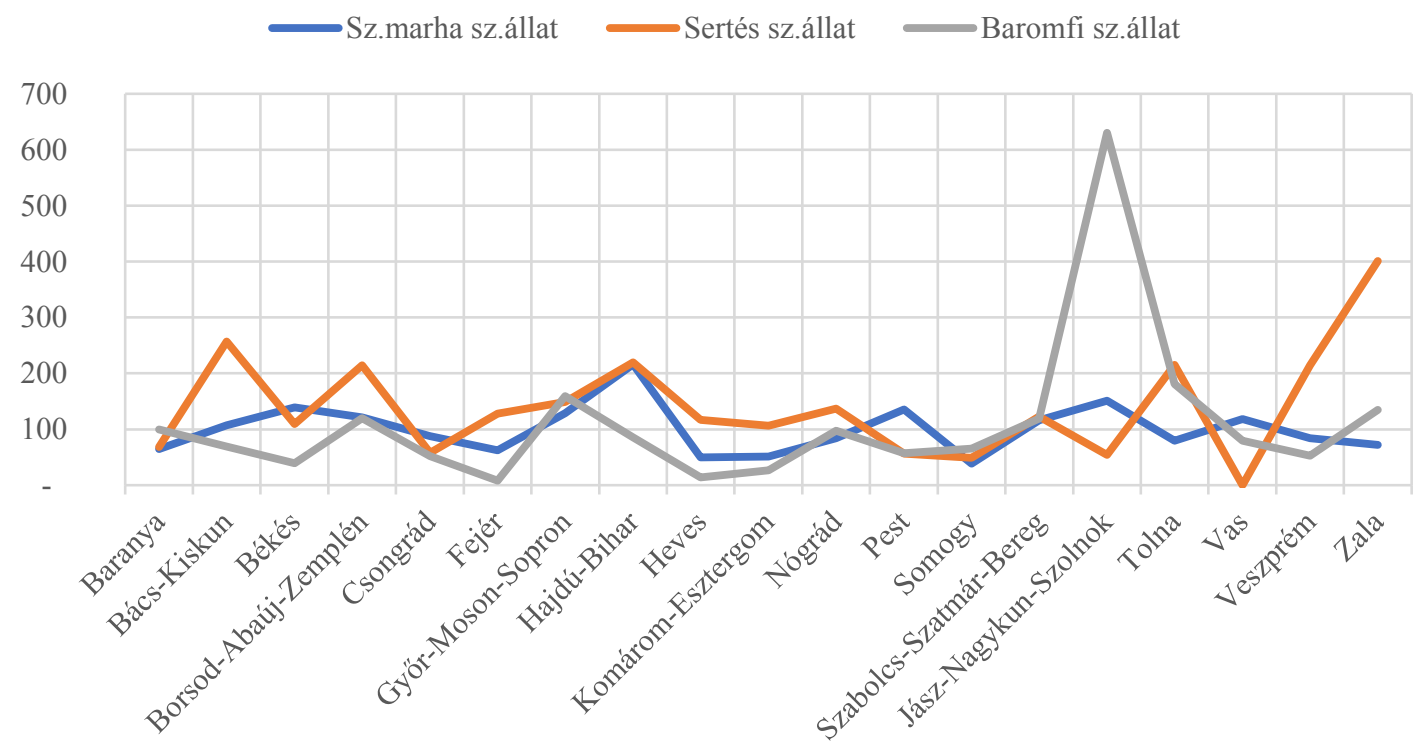

\section{6. ábra: Megyei állatállomány változása, 2010-2015 (\%)}

Forrás: AKI adatok alapján, saját szerkesztés 2019.

Érdemes még az STÉ, azaz a Standard Termelési Értékhez kapcsolódó megyei eredményeket is megnéznünk. A Bizottság (EU) 2015. február 3-i, 2015/220 végrehajtási rendelete az Európai Unióban müködő mezőgazdasági üzemek jövedelmére és üzleti tevékenységére vonatkozó számviteli adatok gyüjtésére szolgáló hálózat létrehozásáról szóló 1217/2009/EK tanácsi rendelet alkalmazására vonatkozó szabályok megállapításáról szóló rendeletben meghatározott módszertan szerint számolja.

Az ágazat kibocsátását fejezi ki termelöi áron hektárra, vagy számolásállatra vetítve euróban. A mutató arra szolgál, hogy összehasonlítható legyen két eltérő tevékenységet végző mezőgazdasági üzem mérete, azé a gazdáé, aki babot termeszt 1 hektáron, azzal a gazdáéval, aki gombát termeszt 50m2-en, vagy mondjuk 5000 libát tart. Megmutatja, hogy az adott állatállománnyal vagy növénykultúrával éves szinten és euróban meghatározva mekkora kibocsátás érhető el. 


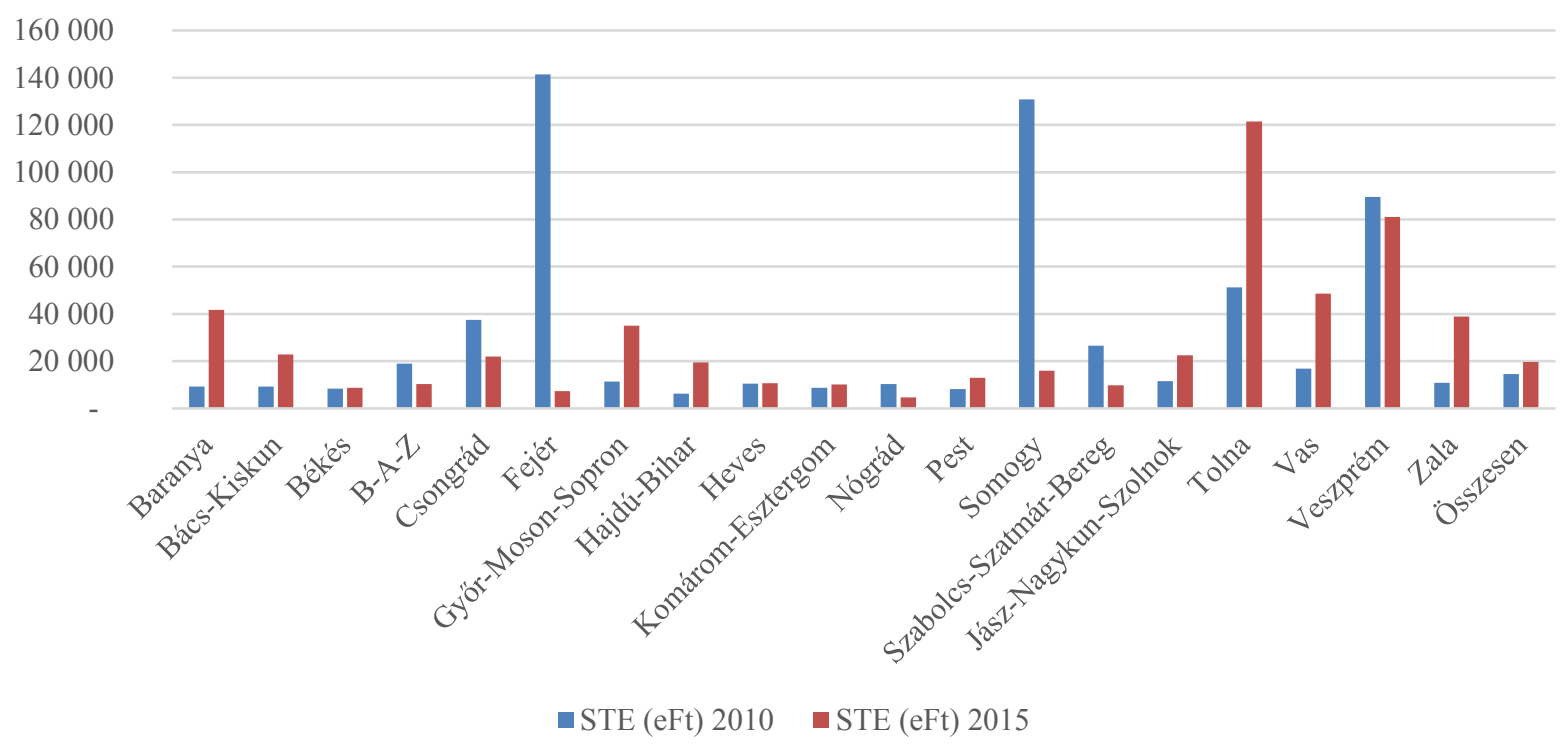

7. ábra: Standard Termelési Érték, 2010, 2015 (eFt)

Forrás: AKI adatok alapján, saját szerkesztés 2019.

Országos szinten az egy üzemre jutó STE érték 36\%-kal nőtt, vagyis a beruházási támogatások üzemekre ható koncentrációs hatása is beigazolódni látszik. A fejlesztési támogatásokat inkább a nagyobb üzemmérettel rendelkezők veszik igénybe (különösen igaz ez az ÁTK intézkedésekben részt vevőkre), ami által az ő üzemeik mérete tovább nő.

A standard termelési érték tekintetében igen nagy megyei differenciákat lehet megfigyelni a 7. ábrán, ezek az igen markáns különbségek jól mutatják milyen eltérő termelési eltérések rajzolódnak ki és ez az érték milyen drasztikusan változott a vizsgált 6 év alatt a megyéknél, melyek mögött komoly hatékonysági elemek is meghúzódnak. Míg Fejér és Somogy megye igen komoly deficitet könyvelhet el addig Baranya, Zala, Tolna és Hajdú-Bihar és GyőrMoson-Sopron pedig emelkedő pályán mozog.

Az eddigiek alapján megállapítható, hogy az állatlétszám és az üzemméretek tekintetében a támogatások pozitívan hatottak, vagyis a célként kitüzött növekedés extenzív módon részben teljesült.

Azonban a támogatásokkal szemben másik elvárt igény - a jövedelem növekedése már jóval vegyesebb képet mutat, azaz a támogatások egyes esetekben nemhogy nem javították a gazdálkodás jövedelmezőségét, hanem rontottak is azon, pl. a megnövelt, de kihasználatlan kapacitások, vagy a megkövetelt, de jövedelmet nem termelő beruházási elemek miatt, mint pl. egy trágyatároló építése.

A gazdálkodás eredményességének fontos mutatója, hogy hogyan alakult a vállalkozás „újérték termelö" képessége. Ezt a termelési érték mutatók fejezik ki, amelyek közül már párat elemeztem az előzőekben. Ezek egy része bruttó, más része nettó mutató. A legfontosabb termelési mutatók a bruttó termelési érték, a bruttó hozzáadott érték és a nettó termelési érték.

A piacgazdaságban tanácsos, hogy a piaci szereplők számára szükséges minőségü és mennyiségű információ álljon rendelkezésre az érdeklődési körükbe tartozó vállalkozások vagy vállalkozási csoportok, ágazatok vagyoni, pénzügyi és jövedelmezőségi helyzetéröl. Miközben 
a jövedelmezőség csak pénzértékben mérhető, addig a gazdasági hatékonyság mérésénél naturális és vegyes mértékegységeket is szokás alkalmazni.

A nettó termelési érték, más néven nettó hozzáadott érték a bruttó hozzáadott érték értékcsökkenési leírással (amortizációval) csökkentett értéke. Jól tükrözi a vállalkozások tényleges teljesítményét, ugyanis megközelítően a létrehozott új értéket mutatja. A gazdasági elemzés során túlnyomó részt a hatékonyság-vizsgálatoknál elterjedt.

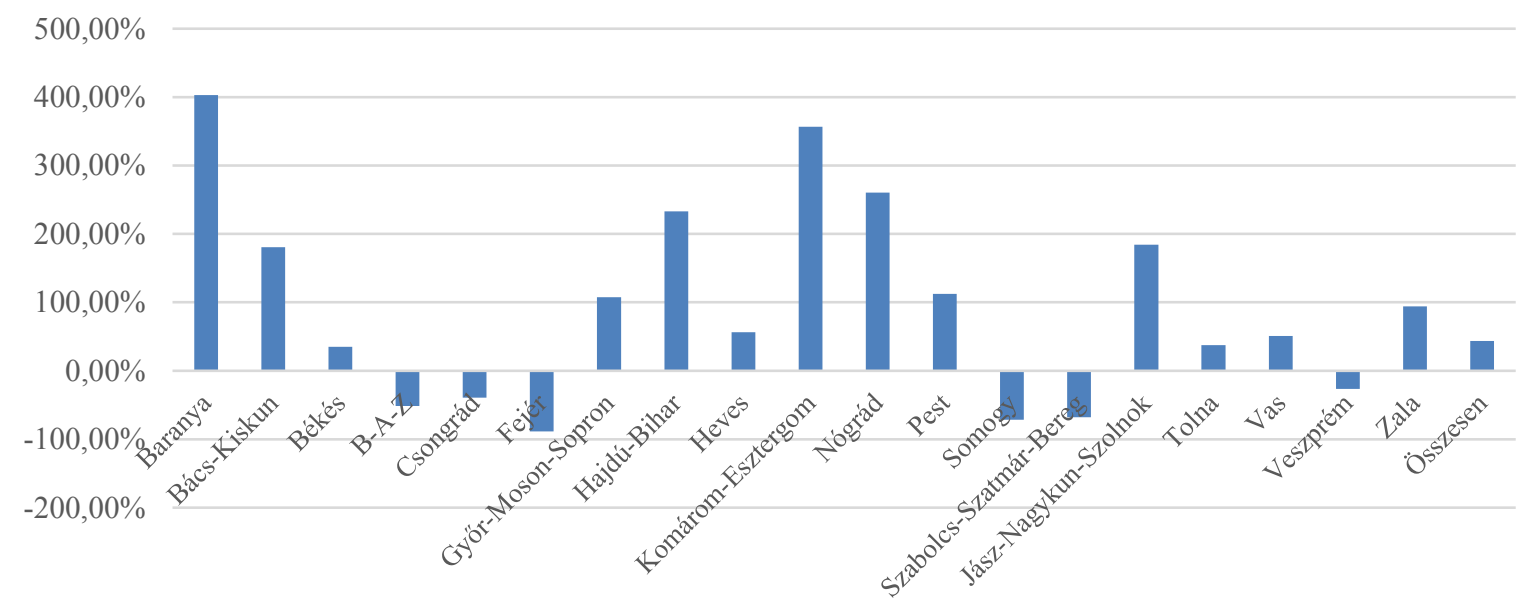

8. ábra: Mezőgazdaság nettó hozzáadott érték változása, 2010-2015 (\%)

Forrás: AKI adatok alapján, saját szerkesztés 2019.

Mivel a nettó termelési érték a termelési érték és a termelés során felhasznált termékek és szolgáltatások és az amortizáció különbségét jelenti, jól mutatja adott ágazat működési sajátosságát, és hatékonyságát.

A müködési hatékonyság vonatkozásában a vizsgált hat év alapján a megyék túlnyomó része pozitív változásokat élt meg, hat megye kivételével. A százalékosan kimutatott változások alapján vannak olyan megyéink, melyekben 200, 300 vagy akár 400 \%-ban nőtt a hatékonyság természetesen ezek a változások mindig erősen függenek a bázis évben produkált értékektől is.
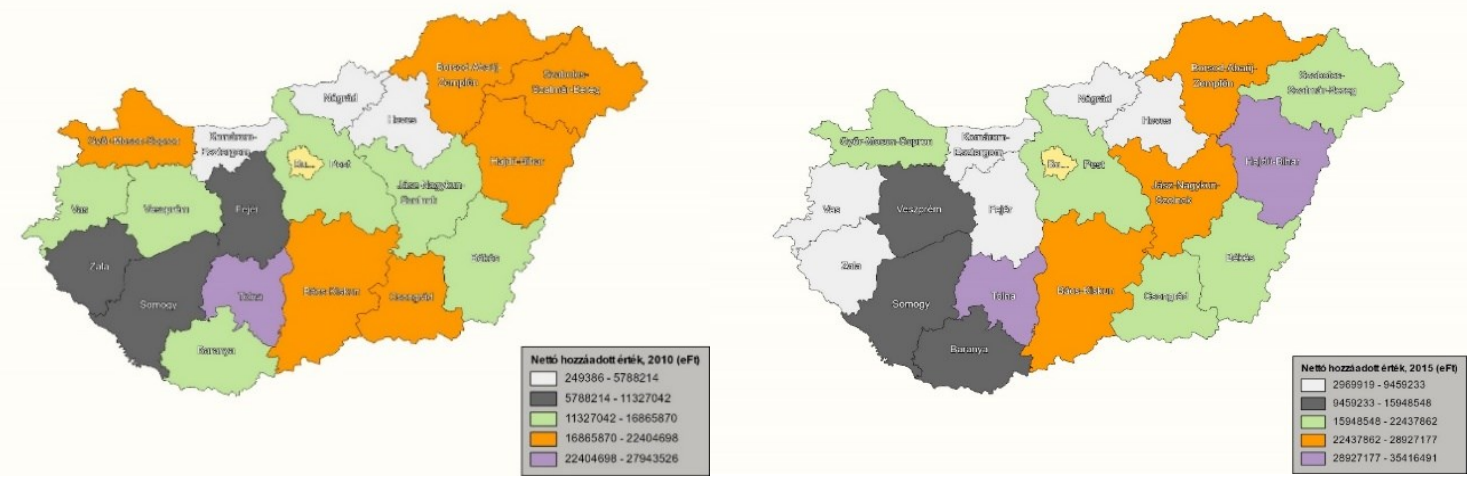

9. ábra: Mezőgazdaság nettó hozzáadott érték, 2010 és 2015 (eFt)

Forrás: AKI adatok alapján, saját szerkesztés 
A megyéket kvintilesekre bontva a nettó hozzáadott érték szempontjából az előzőekhez hasonlóan szintén eltérő fejlődési pályákat állapíthatunk meg. A legjobb 20\%-ba a támogatásoknak is köszönhetően bekerült Tolna megye mellé Hajdú-Bihar megye. Javított besorolásán Jász-Nagykun megye, nem változott közepes besorolásán a rangsorban Pest, Békés, Somogy, míg a többi megye esetében a nettó hozzáadott értéket tekintve visszarendeződés állapítható meg.

Ez a folyamat természetesen nem vagy nem csak a támogatások számlájára írható, hanem egyéb gazdasági folyamatok is szerepet játszanak a folyamatokban, mint pl. a tejár ciklikussága, a sertésciklus, a baromfi influenza, melyek mind megfigyelhetők voltak a vizsgált időszakban.

Ha a mezőgazdaságban nettó hozzáadott értékében bekövetkezett átalakulásokat tekintem át, már nem tapasztalhatók olyan nagy eltérések néhány kivételtől eltekintve, mint a tárgyi eszközök vonatkozásában. Ezen kivételekre jó példa és elgondolkodtató Nógrád több mint tizenegyszeres javulása, az átlagos $120 \%$-os pozitív változáshoz képest.

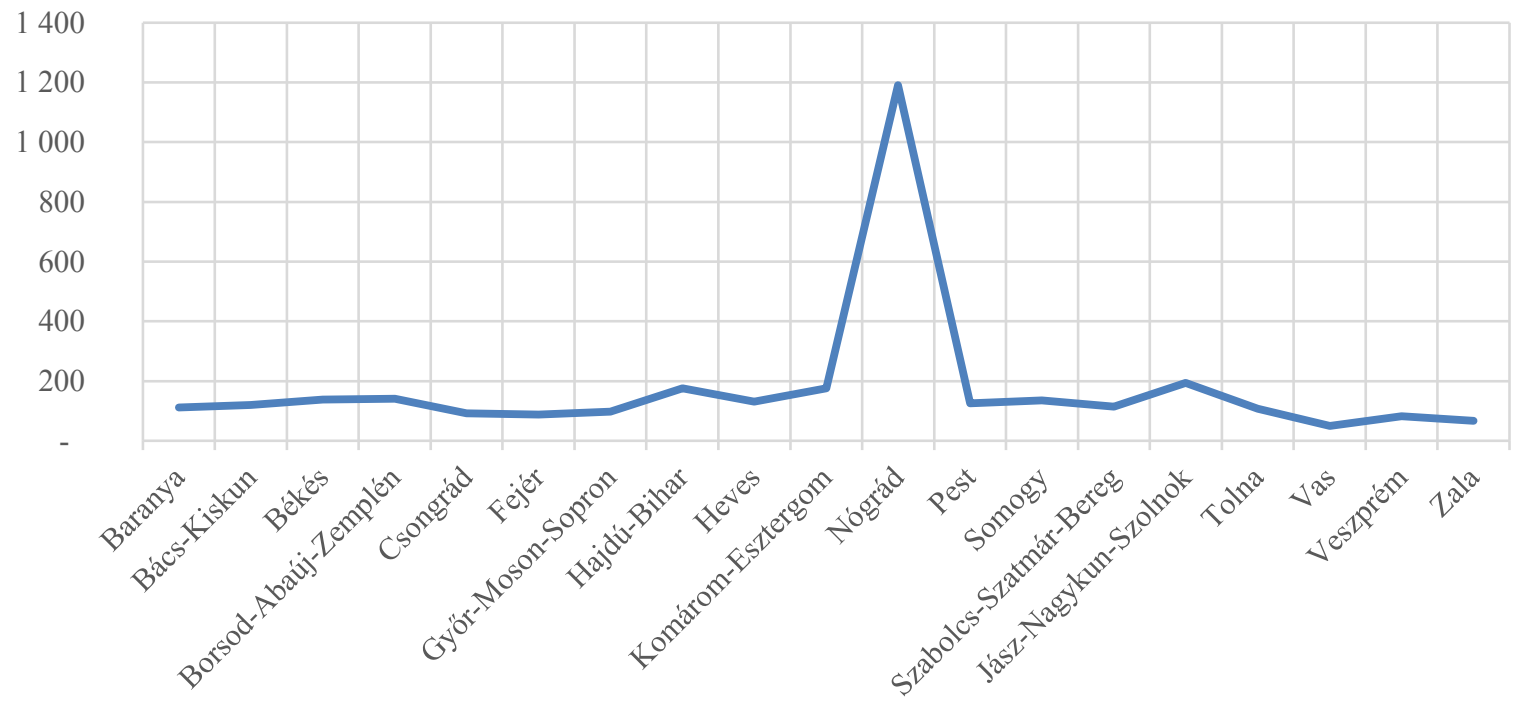

10. ábra: Mezőgazdaság nettó hozzáadott érték változása, 2010-2015 (\%)

Forrás: AKI adatok alapján, saját szerkesztés

Több megye (Vas, Zala, Vesztprém) erösen $100 \%$ alatt maradt, páran jól közelítették és így majd megduplázták teljesítményüket (Csongrád, Fejér, Győr-Moson-Sopron), a többi megye igen komoly fejlödést tudott realizálni, sokan közülük a 200\%-ot is közelítették. (10. ábra)

Az adózás előtti eredményekben is igen meghatározó változásokat sikerült feltárni. KomáromEsztergom majd 500\%-kal, míg Nógrád majd 200\%-kal maradt el a 2010-es eredményétől, oly módon, hogy közben több megye is majd megháromszorozta (Borsod-Abaúj-Zemplén, HajduBihar, Heves) vagy négyszerezte, (Jász-Nagykun-Szolnok) adózás elötti eredményének az értékét. (11. ábra) 


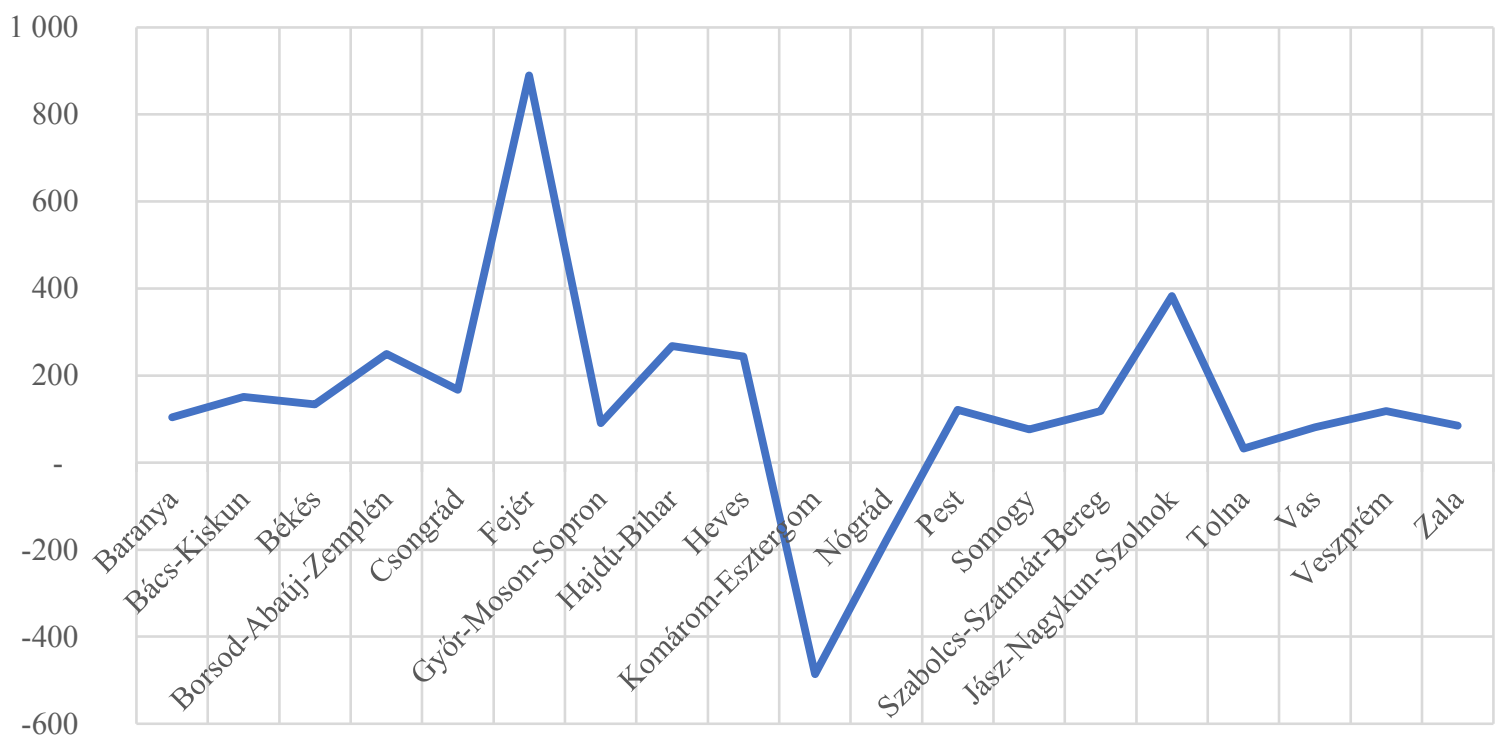

\section{1. ábra: Mezőgazdasági vállalkozások adózás előtti eredményének változása, 10-15 (\%)}

Forrás: AKI adatok alapján, saját szerkesztés

A fentiekben leírtak a fejlesztési támogatások megoszlásának a tükrében válnak igazán érdekessé (12. ábra), mivel ha a két ábrát egymáshoz képest elemezzük igen egyszerüen megállapítható, hogy nem azokban a megyékben a legmarkánsabb a tárgyi eszköz állomány növekedése, amelyek a legtöbb támogatáshoz jutottak a vizsgált időszakban.

Amennyiben összevetjük a megyékben a specializált állattartó gazdaságok összes tárgyi eszköz állományát a megyékben kiutalt támogatási összegekkel, akkor igen vegyes képet kapunk. A sor elején álló Baranya megye szerény összegü támogatását szerény mértékü tárgyi eszköz csökkenés követte, ami igaz még Fejér és Vas megyékre is.

Bács-Kiskun megyében kifizetett 40 Mrd forint támogatás 7,1 Mrd forinttal növelte az eszközállományt, mely tény további vizsgálatokat indokolna. Békés, B-A-Z és Csongrád megyékben a $10 \mathrm{Mrd}$ forint körüli támogatások igen jelentős eszközállomány növekedéssel jártak együtt.

A kiemelkedő mértékű támogatást kapó Hajdú-Bihar és Pest megye eszközállományát csak szerény mértékben növelte, sőt utóbbi esetben csökkenés látható. Ez Pest megye esetében azt is jelentheti, hogy felhasznált adatbázis nem 100\%-ban megbízható, mert ha pl. egy Budapestre bejelentett cég, beruházása vidéken valósul meg, akkor a figyelembevétel hibás.

Szabolcs-Szatmár-Bereg, Jász-Nagykun-Szolnok, Veszprém, Zala és Tolna megyékben igen pozitív a kép, a közepes mértékü támogatás mellett mindhárom megyében jelentősen nőtt a tárgyi eszköz állomány a vizsgálat időszakban.

Ez a megállapítás elsősorban Tolna és Jász -Nagykun-Szolnok megyékre nem igaz. De azt is meg kell állapítanom, hogy voltak olyan megyéink (Hajdú-Bihar, Borsod-Abaúj-Zemplén, Győr-Moson-Sopron), amelyek arányaiban alacsony összes megyei támogatás mellet magas STE változást tudtak produkálni. 
Heves és Komárom-Esztergom megyékben az alacsony támogatási igényeket, alacsony kifizetett összegek követték, melyek eredőjeképpen az állattartó telepek tárgyi eszközállománya a vizsgált időszakban kiemelkedő mértékben csökkent.

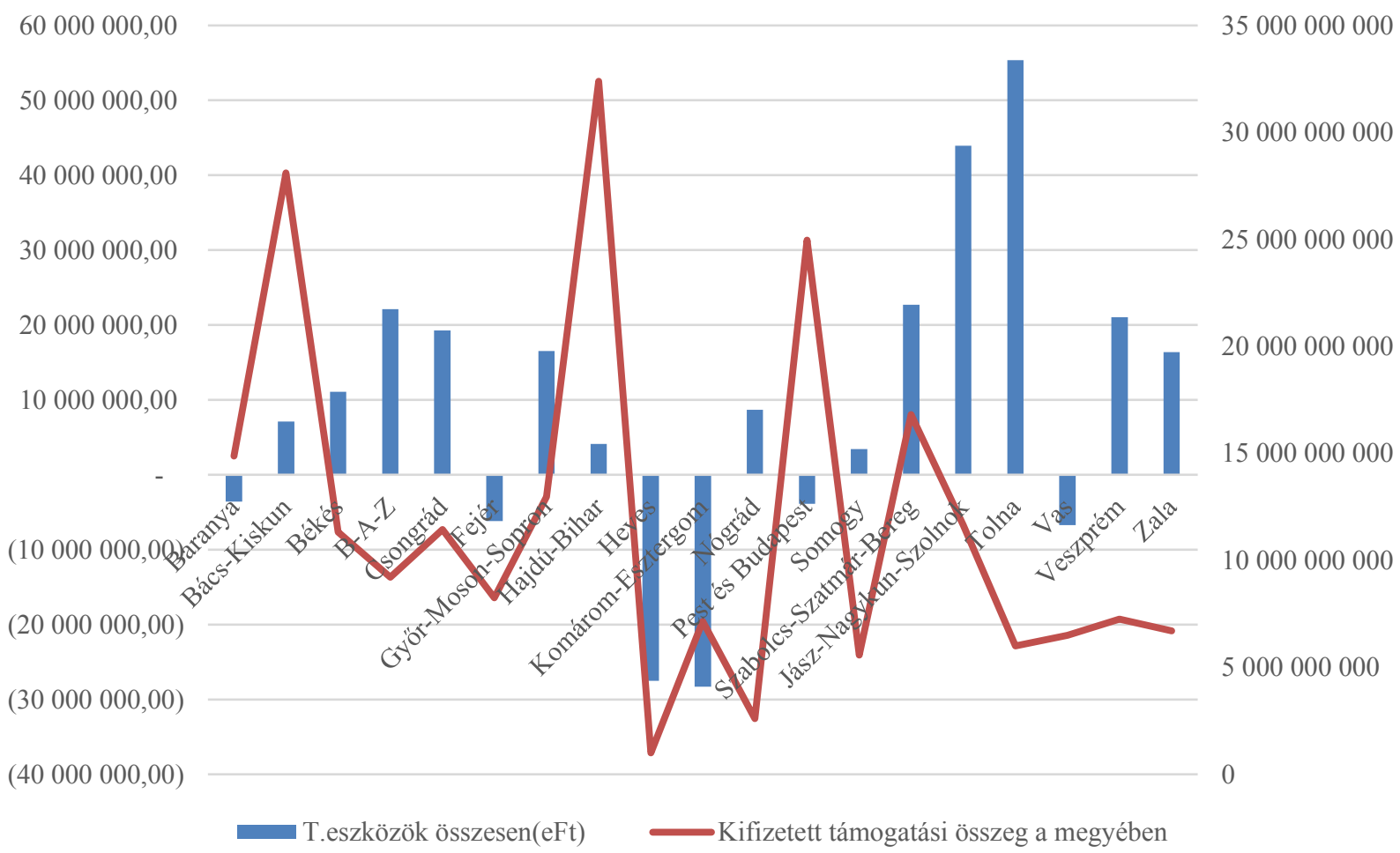

\section{2. ábra: A vizsgált hat év alatt kapott összes fejlesztési támogatás és a termelési eszközök változása, 2010-2015 (eFt)}

Forrás: IIER és AKI adatok alapján, saját szerkesztés 2019.

Az eddigi elemzések alalapján számos összefüggést tudtam kimutatni, de a vizsgálataim sajnos abban nem tudtak megerősíteni, hogy a felhasznált támogatások meghatározó módon és egyöntetűen tudtak volna pozitív hatást gyakorolni a megyék állattartására.

Az előző ábra alapján sajnos az rajzolódik ki, hogy az elnyert támogatások és a termelési eszközök változásában érdekes módon nem mindig mutatható ki szoros kapcsolat. Vannak olyan megyéink, ahol viszonylag magas támogatási összeg mellett a tárgyi eszközállomány nem növekedett, sőt erős hanyatlást mutatatott a vizsgált időszakban.

\section{Következtetések, javaslatok}

Az Új Magyarország Vidékfejlesztési Program forrásainak elosztásában igen markáns eltéréseket mutattam ki. A gazdák számára történő méltányos támogatások csökkentik az ágazati jövedelmekhez kapcsolódó bizonytalanságokat a jól müködetethető birtokszerkezet kialakulását, amik alapját képezik a vidéki térségekben a népesség megmaradásnak, de ennek ellenére sajnos a támogatások területi szempontú vizsgálata alapján igen nagy eltéréseket lehetett kimutatni. 
Kutatásaim alapján az alábbi fő megállapítások fogalmazódnak meg:

- A korábbi fejlesztési program végrehajtása során szerzett tapasztalatok nem teljes körüen kerültek beépítésre az új fejlesztési programokba.

- Nem igazolható, hogy a vizsgált pályázati rendszer Magyarországon csökkentette a területi különbségeket, sőt számos esetben ennek az ellenkezőjét segítette elö.

- Az alkalmazott pályázati bírálati rendszerek sajnos nem azokhoz a célokhoz vezetnek, melyek a fejlesztési programokban megfogalmazásra kerültek.

- Szükséges lenne a pályázati bírálati rendszereket fejleszteni a rendelkezésre álló adatok alapján és minimális további adatgyüjtés alapján.

- Szükséges olyan statisztikailag is alátámasztott megoldás, mely az egyes szempontokat a lehető legjobb eredmény elérése érdekében megfelelően súlyozza.

\section{Irodalomjegyzék}

1. Hajdú Z. (1989): Az első „Szocialista” településhálózat-fejlesztési koncepció formálódása Magyarországon (1949-1951). Tér és Társadalom, 1. sz. 6-11.

2. Tóth T. - Káposzta J. (2014): Tervezési módszerek és eljárások a vidékfejlesztésben, Szent István Egyetemi Kiadó Gödöllö, 158p.

3. Tóth T. (2019): Sikeres/jó önkormányzati müködés gazdaságbiztonsági és szociális/társadalmi biztonsági dimenziói Gödöllö, Magyarország, Szent István Egyetemi Kiadó (2019), 148 p.

4. Bakos I.M.-Tóth T. (2016): Special Steps of Local Economic Development for Improving Food Buying Groups 13th Annual International Conference on Economics and

Business http://www.szrtt.ro/attachments/article/41/conf_21_oct_section_proceedings.pdf

5. Káposzta J. (2001): Regionális gazdaságtan, Gödöllő DOI: 10.18531/Studia.Mundi.2016.03.01.52-61 